\title{
IDENTIFYING THE 'OUTSIDER': AN ASSESSMENT OF FOREIGNER TRIBUNALS IN THE INDIAN STATE OF ASSAM
}

\author{
TALHA ABDUl RAHMAN*
}

\begin{abstract}
The State of Assam in the Union of India has a peculiar history of the movement of people from across India's international borders into Assam. There is no credible way to arrive at specific numbers. Arrival of people in Assam has become a point that has been abused by those in power to utilise local sentiments regarding the dilution of 'Assamese culture'. This article briefly discusses the timelines leading up to the preparation of the Assam's National Register of Citizens that presently excludes approximately 1.9 million residents. The citizenship status of those excluded is to be determined by Foreigners Tribunals ('FT') functioning under the Foreigners Act, 1946 - a post-Second World War and pre-Constitution legislation whose validity is also in doubt. This article examines the Foreigners Act, 1946, as well as the constitution and performance of the FTs with reference to the yardsticks of the rule of law and constitutional values. Towards this end, the article analyses the law discernible from the judgments of the Indian Courts as well as some judgments of the Assam High Court and the FTs. It concludes by stating that the framework of adjudication by FTs is not able to keep up with the promise of effective adjudication under the Constitution of India. It calls for an urgent need for academic scrutiny of all aspects of the citizenship verification process in India.
\end{abstract}

\section{TABLE OF CONTENTS}

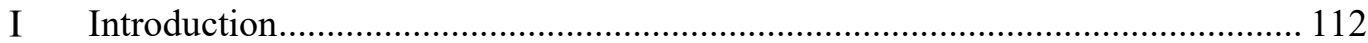

II Contextualising The Problem of the 'Outsider' in Assam.................................... 114

III The Rule of Law .......................................................................................... 119

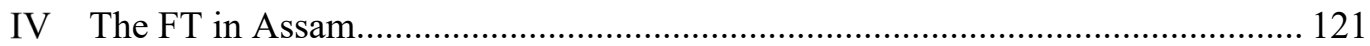

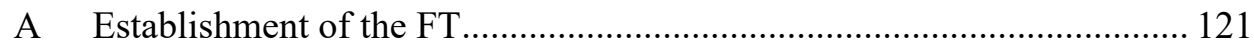

B Selecting Members for the FT .................................................................. 124

C Applying the Criteria of 'Judicial Experience' to the Selection Process. 126

D Lack of Transparent Selection Process and Lack of Judicial Training..... 128

E Members of FTs Lack Decisional Autonomy ......................................... 129

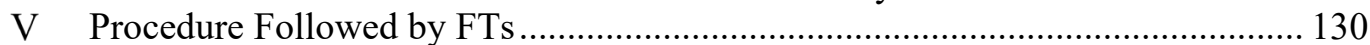

A Due Process Guarantees Are Not Available in FTs.................................. 131

B FTs' Power to Devise Their Own Procedure............................................ 133

VI Conclusion: 'Designed to Exclude' ..................................................................... 136

\section{INTRODUCTION}

The publication of the National Register of Citizens ('NRC') in August 2019, which excluded 1.9 million persons in Assam, India, from the list of citizens, has given rise to much domestic and international concern regarding the risk of statelessness and serious violations of other rights likely to ensue. To date, however, there has been no comprehensive analysis of the legitimacy of the

* Talha Abdul Rahman (BA, LLB (Hons) (NALSAR, India), BCL (Oxon), Advocate on Record, Supreme Court of India, New Delhi. Visiting Fellow (2020), Peter McMullin Centre on Statelessness, Melbourne Law School, University of Melbourne. The author acknowledges that this work has immensely benefited from the Visiting Fellowship and support from Peter McMullin Centre on Statelessness, Melbourne Law School, University of Melbourne. 
process, and in particular of the Foreigner Tribunals ('FTs'), which are designed to identify whether those excluded are citizens or 'foreigners'. This article fills this gap by undertaking a close examination of whether the FTs comply with the fundamental precepts of the rule of law. The article also seeks to contextualise the current controversy in light of the history of the region and ongoing discussion about the fundamental nature of the Indian state.

The Indian State of Assam is located south of the Eastern Himalayas in North East India and shares its borders with Bhutan and Bangladesh, and certain other Indian States including West Bengal. Even though the citizenship crisis in Assam could be said to have been brewing since the 1960s, there appears to be a lack of legal academic work that analyses the Indian citizenship determination process followed by FTs generally or with specific reference to the Indian State of Assam. The issue has reached the Supreme Court of India as well on several occasions, but the issues that have been raised and dealt with in this article have not been dealt with by the Supreme Court of India.

After the Partition of British India into India and Pakistan in 1947, India chose to be a secular country where Muslims constitute about 13.4 per cent of the population and Hindus constitute the majority. ${ }^{1}$ The government of India has proposed a pan-India National Population Register that includes questions on citizenship, and has also enacted the Citizenship (Amendment) Act, 2019, ${ }^{2}$ which allows Hindus from certain neighbouring countries to gain Indian citizenship through administrative procedures. It is perceived that Hindus who are left out from being identified as Indian citizens after a determination by a FT would be allowed to regain their citizenship using the Citizenship (Amendment) Act, 2019. These developments as a whole, therefore, raise questions about the potential role of the FTs in a broader ethno-nationalist project that results in marginalising Muslim citizens of India.

In addition, the identification of doubtful citizens and 'foreigners' in the Indian State of Assam assumes importance in the international context, because it raises concerns about limitations on sovereign power to determine nationality arising from international human rights law and the Constitution of India ('the Constitution'). The experience from the Indian State of Assam is also relevant because the Indian Government may implement the 'Assam Model' across India, resulting in a disproportionate rise of stateless persons globally, at a time when the United Nations is actively pursuing the reduction of statelessness across the globe.

In this article I explain the context of the identification of Indian citizens in which the FTs have been functioning in the Indian State of Assam. This paper argues that FTs have not been established by law but by an administrative order, resulting in a weak tribunal whose judges are not independent and whose procedures are not fair. The article explores whether the constitution and function of FTs in Assam fulfils rule of law guarantees. It concludes that FTs in their present form operate oppressively, often resulting in a miscarriage of justice that cannot be corrected by limited judicial review.

Part II begins by providing an important historical overview in order to understand the context of the NRC process. Part III then explains the article's conception of the rule of law, against which the FTs will be assessed. Part IV

1 'Religion', Office of the Registrar General \& Census Commissioner, India (Web Page, 2001) $<\mathrm{https}$ ://censusindia.gov.in/Census_And_You/religion.aspx $>$.

2 See Farrah Ahmed, 'Arbitrariness, Subordination and Unequal Citizenship' (2020) Indian Law Review (online), citing Citizenship (Amendment) Act 2019 (India) Law No 27 of 2019. 
outlines and critiques the establishment and constitution of the FTs, while Part V examines and analyses how they function. For the purposes of considering the onthe-ground situation in the Indian State of Assam, this article relies on newspaper articles and coverage by non-governmental organisations ('NGO'), and for other issues the article follows a doctrinal analysis. This article focuses on procedural issues inherent in the FT process. While it is relevant to examine the validity of the substantive law that is applied by FTs, this is beyond the scope of the present article.

\section{ConteXtualising The Problem of The ‘OUTSideR’ In Assam}

The social 'problem' of the 'outsider' in the Indian State of Assam is not new. ${ }^{3}$ Throughout the nineteenth century, successive rulers and governments encouraged the settlement of outsiders in various parts of Assam - in the Brahmaputra river valley for cultivation or on the hilly slopes for cheap labour in tea gardens. The partition of Bengal in 1905 that created separate electorates for Hindus and Muslims in West Bengal and East Bengal and Assam only amplified the differences and insecurity. ${ }^{4}$ However, even within the State of Assam, historically there has been a distinction between those residing in the hills of Assam and those in the plain or the Brahmaputra valley. This division can be seen in the acknowledgement of Autonomous Districts in the Hills of Assam on the one hand and the rest of Assam on the other. ${ }^{5}$ However, in order to gain political unification of the people of Assam, a common enemy - the Bengali speaking outsider from East Bengal - was created, ${ }^{6}$ and this enemy was projected as a 'chauvinistic Bengali' speaking people who even considered the Assamese language a mere dialect of Bengali and looked down upon the 'tribal' Assamese. However, focused resentment against Bengali speaking Muslims is a sentiment that developed after the partition of 1947 with the sharp rise in communal sentiments. ${ }^{7}$

The earliest instance of the law regulating the presence of 'foreigners' in India was in 1864, six years after the British Crown took over the administration of India from the East India Company. ${ }^{8}$ The need for better regulation of foreigners in British India arose in the context of tension prior to World War II and summary removal of foreigners from India for which the Foreigners Ordinance, 1939 was promulgated, soon replaced by Foreigners Act, 1940. ${ }^{9}$ After World War II, the

3 See Navine Murshid, 'Assam and the Foreigner within: Illegal Bangladeshis or Bengali Muslims?' 56(3) Asian Survey 581.

4 Ramesh Chandra Majumdar (ed), The History and Culture of the Indian People: Struggle for Freedom (Bharatiya Vidya Bhavan 1969) 21; Anil Baran Ray, 'Communal Attitudes to British Policy: The Case of the Partition of Bengal 1905' (1977) 6(5) Social Scientist 34, 39.

5 See Monirul Hussain, 'Tribal Movement for Autonomous State in Assam' (1987) 22(32) Economic and Political Weekly 1329.

6 See Murshid (n 3) 583-84:

The diffusion of such ideas in the public sphere set the stage for the Assam Movement of 1979, which concretized what it meant to be a foreigner, not just for the Asomiya-speaking population but also for the different tribes and ethnic groups in the region, by identifying the 'common enemy'.

7 ibid 590.

8 The Government of India Act, 1858 (UK) 21 and 22 Vict c 106.

9 Hans Raj, Executive Legislation in Colonial India 1939-1947: A Study of Ordinances Promulgated by the Governor General of India (Anamika Pub \& Distributors 1989) 8, citing Foreigners Ordinance, 1939 (India); Foreigners Act, 1940 (India) Act No II of 1940 (repealed). 
Foreigners Act, 1946 was enacted, ${ }^{10}$ which barely provided for any modern substantive law or procedural law guarantees. It is relevant that s 7 of the wartime legislation - the Foreigners Act, 1940 (repealed) and s 9 of the Foreigners Act, 1946 (currently in force) both provide for a reverse burden of proof, ie the person accused of being a foreigner is required to establish that he or she is not a foreigner. ${ }^{11}$ The Foreigners Act, 1946 was judicially found to give far-reaching powers to the Executive, ${ }^{12}$ because foreigners were regarded as having no rights.

However, the partition of British India into secular India and the Islamic Republic of Pakistan - then comprising of West Pakistan (now Pakistan) and East Pakistan (now Bangladesh) - in 1947 led to further migration (largely of Bengali Hindus) of people into Assam, which was part of secular India. ${ }^{13}$ There are no confirmed statistics on the scale of the migration that took place; however, it is argued that many Hindu Bengalis had crossed over to Assam from then East Pakistan. This led to the enactment of the Immigrants (Expulsion from Assam) Act, 1950 in order to protect the indigenous inhabitants of Assam. ${ }^{14}$ The Immigrants (Expulsion from Assam) Act, 1950 provided for the expulsion of a 'foreigner' from Assam if their presence was 'detrimental to the interests of the general public of India' but did not apply to any person who had fled from East Pakistan on account of civil disturbances. ${ }^{15}$ The 1950 Nehru-Liaquat Agreement ('Nehru-Liaquat Pact') allowed minorities from India and Pakistan the freedom of movement and assurance that they would get back their immovable properties if they returned by 31 December 1950. ${ }^{16}$

In the year 1951, the government of India also ordered the preparation of the NRC for Assam - an exercise of enumeration that is said to have been completed in 20 days. ${ }^{17}$ Thus, while the Nehru-Liaquat Pact guaranteed safe passage, many Indian families did not return until after the 1951 census-cum-NRC exercise was complete in March, 1951.18 Consequently, those who did not return were left out from the 1951 Census. Thus, for this and many other reasons including the impossibility of travelling vast tracts of lands in the geographically challenging terrain of Assam, the NRC of 1951 excluded many. It is this $1951 \mathrm{NRC}$ that today forms a key determinant in whether the residents of Assam are in fact Indians.

The power to identify foreigners remained the exclusive preserve of the 'Central Government' under the Immigrants (Expulsion from Assam) Act, 1950 as well as the under the Foreigners Act, 1946 - the former being a special law

10 ibid 150-51, citing Foreigners Act, 1946 (India) Act No 31 of 1946.

11 Due to the shared history, the almost identical Foreigners Act, 1946 (n 10) applies in Bangladesh and Pakistan.

12 See Bawalkhan Zelanikhan v B C Shah, [1958] AIR 1960 Bom 27 (Bombay High Court).

13 This migration was in addition to those migrations that had been encouraged during the British rule for commercial reasons. The need for cheap labour in Assam Valley fuelled a policy of migration to Assam.

14 Immigrants (Expulsion from Assam) Act, 1950 (India) Act No 10 of 1950.

15 ibid ss 2, 2(b).

16 Agreement between the Governments of India and Pakistan Regarding Security and Rights of Minorities (Nehru-Liaquat Agreement), India-Pakistan, 1 India BTA 243 (signed and entered into force 8 April 1950) art B(v).

17 Ipsita Chakravarty, 'Why Did Assam Prepare the 1951 NRC, Which Has Become a Touchstone for Citizenship Today?', Scroll.in (online, 27 July 2019) $<$ https://scroll.in/article/931879/why-did-assam-prepare-the-1951-nrc-which-has-become-atouchstone-for-citizenship-today>.

18 See Rafiul Ahmed, 'Latitudes of Anxieties: The Bengali-Speaking Muslims and the Postcolonial State in Assam' in Asia in Pinar Bilgin and L H M Ling (eds) International Relations: Unlearning Imperial Power Relations (Routledge 2017) 48. 
applicable to Assam alone. ${ }^{19}$ Over the years, some steps were taken by the Central Government to identify and expel 'foreigners', but the numbers of 'outsiders' identified could not pacify the sentiments of the Assamese groups who wanted their territory purged of Bengali speaking persons, and especially Bengali speaking Muslims who were accused of migrating from East Pakistan to Assam. ${ }^{20}$ In 1971, Bangladesh won its freedom from Pakistan, which was persecuting the residents of East Pakistan (now Bangladesh) on linguistic lines. This also resulted in Bengali speakers migrating to India, particularly the culturally similar provinces of Assam and West Bengal. ${ }^{21}$

Between 1979 and 1985, there was a massive movement led by students of Assam to protect Assamese culture. ${ }^{22}$ The movement gained popular support when it was projected that the change in the voting population of Assam as compared to the previous decade was disproportionate, and could affect the election outcome. ${ }^{23}$ The protests ended with the inking of the Assam Accord between the government of India, the government of Assam and the All Assam Students Union and the All Assam Gana Sangram Parishad - bodies that were representing the protestors. ${ }^{24}$ The Assam Accord of 1985 obliged the government of India to identify who arrived in India after 24 March 1971 and expel them from India as 'foreigners' after disenfranchising them. ${ }^{25}$ Those who were found to have arrived between 1 January 1966 and 24 March 1971 were to be disenfranchised for a period of 10 years from the date of their detection, but were not to be rendered stateless. ${ }^{26}$

The government also undertook to examine the dissatisfaction of the people of Assam with the manner and the pace at which the process of identification of foreigners was taking place in Assam. It was thus agreed that any person who was residing in Assam prior to 24 March 1971 would be regarded as an Indian citizen, and thus, the general rules that apply to the rest of India would not apply to Assam. Subsequently, in order to ensure that a non-citizen does not vote, the Election Commission of India took upon itself the task of 'doubting' the citizenship of Assamese residents, which resulted in the exclusion of lakhs of voters, mostly women, as they were marked as 'D Voter'. ${ }^{27}$

In 1983, the government of India had enacted the Illegal Migrants (Determination by Tribunal) Act, 1983, which was

19 Immigrants (Expulsion from Assam) Act, 1950 (n 14) s 2; Foreigners Act, 1946 (n 10) s 3.

20 Vani K Borooah, 'The Killing Fields of Assam: Myth and Reality of Its Muslim Immigration' 48(4) Economic and Political Weekly, 43, 43-44.

21 See generally Rounaq Jahan, 'Genocide in Bangladesh' in Samuel Totten and William S Parsons (eds), Centuries of Genocide: Essays and Eyewitness Accounts (Routledge 2013) 249.

22 Sanjib Baruah, 'Immigration, Ethnic Conflict, and Political Turmoil — Assam, 1979-1985' (1986) 26(11) Asian Survey 1184.

23 ibid 1191-92.

24 'Assam Accord' (1985) 20(33) Economic and Political Weekly 1369, 1369-70, discussing Accord between AASU, AAGSP and the Central Government on the Foreign National Issue (Assam Accord), signed 15 August 1985 (Memorandum of Settlement) $<$ https://peacemaker.un.org/sites/peacemaker.un.org/files/IN_850815_Assam\%20Accord.pd $\mathrm{f}>$ ('Assam Accord'). Assam Accord (n 24) art 5.8.

26 ibid arts 5.2-5.6.

27 A 'lakh' is a unit of 100,000 in the Indian numbering system. Nazimuddin Siddique, 'Discourse of Doubt' (2019) 54(10) Economic \& Political Weekly 25. 
An Act to provide for the establishment of Tribunals for the determination, in a fair manner, of the question whether a person is an illegal migrant to enable the Central Government to expel illegal migrants from India and for matters connected therewith or incidental thereto. 28

The Illegal Migrants (Determination by the Tribunal) Act emphasised 'procedural fairness' and amongst other protections, placed the burden of proof that a person was a foreigner upon the government. ${ }^{29}$ Like any other court in India, ${ }^{30}$ the number of cases decided by the tribunal were few, ${ }^{31}$ and it was the burden of proof provision that was alleged to be responsible.

The apparent failure of the Illegal Migrant Determination Tribunal, which was set up in 1983 to meet the expectations of Assamese stakeholders, resulted in the filing of a petition in the Supreme Court by one Sarbananda Sonowal, then a student leader (who is presently the Chief Minister of the State of Assam) challenging the validity of the Illegal Migrants (Determination by Tribunal) Act, 1983. A few years later, in 2005, in Sarbananda Sonowal v Union of India ('Sonowal I'), 32 the Supreme Court of India declared the Illegal Migrants (Determination by Tribunal) Act, 1983 to be invalid because of the procedural fairness it sought to provide was extremely difficult, cumbersome and time consuming. ${ }^{33}$ Incidentally, the Illegal Migrants (Determination by Tribunal) Act, 1983, now invalidated by the Supreme Court of India, also provided eligibility, qualification and condition of service criteria for the members of the tribunal - a feature absent in FTs. Until its invalidation, the Illegal Migrants Determination Tribunal was determining the cases of persons referred to it by the Central Government and other agencies to whom such a power had been delegated. After its invalidation, the power to determine whether a person is a foreigner is exercised by the FT. ${ }^{34}$

Soon after 2005, another public interest litigation was filed in the Supreme Court of India seeking implementation of the amended Indian Citizenship Act, $1955,{ }^{35}$ which empowered the government to create a NRC for Assam, ${ }^{36}$ and sought to enforce the government's promise in the Assam Accord to detect, declare

28 Illegal Migrants (Determination by Tribunal) Act, 1983 (India) Act No 39 of 1983.

29 See ibid s 11.

30 It is reported in June 2019 that there were about 4.5 million cases pending in various High Courts in India. See 'Out of 43 Lakh Cases Pending in High Courts, over 8 Lakh a Decade Old', the Economic Times (online, 27 June 2019) $<$ https://economictimes.indiatimes.com/news/politics-and-nation/out-of-43-lakh-casespending-in-high-courts-over-8-lakh-a-decade-old/articleshow/69974916.cms?from=mdr>.

31 See Sarbananda Sonowal v Union of India [2005] 5 SCC 665 (Supreme Court of India) 682 [8] ('Sonowal I'):

Figures as on 31-3-2000, of total number of inquiries initiated, total number of persons declared as illegal migrants and the number of persons physically expelled have been given. It is specifically pleaded that the IMDT Act is an ineffective piece of legislation and it is standing in the way of detection and deportation of post-1971 foreigners in Assam and, therefore, the same should be repealed.

32 ibid

33 ibid $726[84](1)-(3)$.

34 ibid $726[84](3)$.

35 (India) Act No 57 of 1955.

36 Citizenship (Registration of Citizens and Issue of National Identity Cards) Rules, 2003 (India) GSR 937(E), r 4. Rule 4A differentiates preparation of the National Register of Citizens ('NRC') in Assam from the rest of the country by replacing house to house enumeration with invitation and receipt of applications from all citizens, for collection of specified particulars relating to each family and individual, residing in the state. 
and deport foreigners. This resulted in the Supreme Court of India passing a range of orders and a judgment in Assam Sanmilita Mahasangha $v$ Union of India ('Assam Sanmilita Mahasangha'), directing the creation of the NRC for Assam and supervising its implementation. ${ }^{37}$ Incidentally, later the presiding judge's ethnicity was raised as a ground of bias and he declined to recuse. ${ }^{38}$

The process of preparing the NRC in Assam involved inviting all residents to make an application for inclusion in the NRC based on documents identified by 'stakeholders' as valid proof of being in Assam before 24 March 1971. The Supreme Court in Assam Sanmilita Mahasangha had fixed timelines for completion of this exercise. ${ }^{39}$ After an extension, the exercise was completed when Justice Ranjan Gogoi became the Chief Justice of India. The process resulted in the exclusion of 1.9 million people residing in the State of Assam from the NRC. Pertinently, mere exclusion from the NRC does not necessarily mean that the person is determined to be a foreigner. It must be followed up with a judicial finding by a tribunal that an excluded person is in fact a foreigner. Thus, in due course, either the excluded persons would file an appeal to a FT or the Government would make a formal request to the concerned FT to determine whether such excluded persons are foreigners, which would result in a judicial determination. ${ }^{40}$ Once it is determined that such persons are in fact foreigners and their exclusion from the NRC is justified, they will be rendered stateless and thereafter run the real risk of perpetual detention. The experience of lawyers establishes that deportation would not be an option given that their alleged country of origin is not determined or is unlikely to be determined because many of them are Indians who could not muster proof of the same. ${ }^{41}$

Prior to and independently from the process following the NRC, the Assam Border Police and the Election Commission of India, amongst others, have been making references to FTs to determine whether a person is not a foreigner. ${ }^{42}$ The references are routinely made, without any serious inquiries and often do not even get the name or parentage of the concerned person right. Such a reference triggers a reverse burden of proof. In other words, unless a person has meticulous records from 50 years ago or the Government noted a person's records accurately before 1971, upon making of a reference it is unlikely that a person would be able to prove himself or herself to be an Indian citizen. It is in this context of 'foreigner' identification that this paper argues that the FTs fail to satisfy the test of the rule

37 (2015) 3 SCC 1 (Supreme Court of India) ('Assam Sanmilita Mahasangha').

38 See Apoorva Mandhani, 'Why CJI Gogoi is under Fire for Defending Assam's NRC While It's Still Sub Judice', The Print (online, 6 November 2019) <https://theprint.in/theprintessential/why-cji-gogoi-is-under-fire-for-defending-assams-nrc-while-its-still-subjudice/316032/>; 'Harsh Mander Removed from Deportation Case, CJI Refuses to Recuse', the Quint (online, 3 May 2019) <https://www.thequint.com/news/india/cji-gogoi-asked-torecuse-himself-in-harsh-mander-deportation-case $>$.

39 Sonowal I (n 31) [48].

40 For procedure, cf Foreigners (Tribunal) Amendment Order, 2019 (India) GSR 409(E).

41 See Wadud Aman (Written Testimony, US Commission on International Religious Freedom Hearing on Citizenship Laws and Religious Freedom, 4 March 2020) $<$ https://www.uscirf.gov/sites/default/files/Aman\%20Wadud.pdf $>$.

42 See 'Functions', Assam Border Police (Web Page) <https://police.assam.gov.in/portlet-subinnerpage/functions $>$. Authorised by Letter No PLB.149/2008/Pt/8 (Letter, Government of Assam, 21 October 2009). See also Unstarred Question No 152 to Be Replied on 12/02/2018 (Letter, Assam Legislative Assembly, 12 February 2018); Letter No. 23/AS/96/Vol.III/2931 (Letter, Election Commission of India, 12 November 1997) <https://cjp.org.in/wpcontent/uploads/2018/10/Assam-Legislative-Assembly-Foreigners-Tribunal-12-022018.pdf $>$. 
of law. In the next section, this paper reviews the basic components of the rule of law, against which the FTs will be assessed.

\section{THE RULE OF LAW}

Globally, the rule of law signifies, at its bare minimum, that no power is absolute but is subject to restrictions; and that any abuse of power is amenable to challenge in an independent court. In India, the sovereign power of parliament to legislate is restricted by the Constitution expressly as well as implicitly. ${ }^{43}$ The powers and obligations of the executive as well as limitations on fundamental rights are required to be defined within the legislation. Thus, even the power of the executive is limited by operation of the law. The common law concept of the rule of law is followed and applied in the Indian context.

The rule of law implies that people are informed of their obligations and limits on their liberty in advance, and an independent process is available to determine the consequences of any breach of such obligation or limit. Adherence to the rule of law is vital for the government to derive legitimacy, both internally and externally. In fact, the separation of powers is itself regarded as a fundamental tenet of the rule of law. ${ }^{44}$

World Bank Governance Project data reveals that countries have varied versions of the rule of law and governance, and their systems of administration differ. ${ }^{45}$ Notwithstanding the various shades of the rule of law followed across the globe, certain aspects are considered as a bare minimum — so much so that they are regarded as fundamental human rights under the Universal Declaration of Human Rights. ${ }^{46}$ Article 10 of the Universal Declaration of Human Rights provides that

Everyone is entitled in full equality to a fair and public hearing by an independent and impartial tribunal, in the determination of his rights and obligations and of any criminal charge against him.

This right, translated into binding form in art 14 of the International Covenant on Civil and Political Rights, embodies the right to recourse, which is the essence of the rule of law. ${ }^{47} \mathrm{~A}$ person who is dissatisfied with any legislative or administrative action should have recourse to an impartial tribunal. The absence of a 'fail-safe' judicial tribunal to challenge governmental action signifies a breach of the most fundamental of human rights.

It is the domain of the judicial system to keep a check on the legislative and the executive actions and keep them within their respective limits. This system of checks and balances - ensuring that the framing of the law, its application and its

43 Constitution of India ('the Constitution') art 13 provides that laws inconsistent with rights guaranteed in Part III of the Constitution of India shall be void. These rights are called 'Fundamental Rights'. See Manoj Mate 'State Constitutions and the Basic Structure Doctrine' (2014) 45(2) Columbia Human Rights Law Review 441.

44 Denise Meyerson, 'The Rule of Law and the Separation of Powers' (2004) 4 Macquarie Law Journal 1.

45 See 'Worldwide Governance Indicators', World Bank (Web Page) $<$ https://info.worldbank.org/governance/wgi/>.

46 Universal Declaration of Human Rights, GA Res 217A (III), UN GAOR, UN Doc A/810 (10 December 1948) preamble (' $U D H R^{\prime}$ ): 'Whereas it is essential, if man is not to be compelled to have recourse, as a last resort, to rebellion against tyranny and oppression, that human rights should be protected by the rule of law'.

47 International Covenant on Civil and Political Rights, opened for signature 19 December 1966, 999 UNTS 171 (entered into force 23 March 1976) 
enforcement is within the broad parameters of the agreed basic notions - is what constitutes the premise of the rule of law. ${ }^{48}$ In addition to the restrictions and limitations imposed by legislation and the constitution, the power of an adjudicator is constrained by rules of interpretation and precedent. The power allocated to a judge is also meant to be exercised for keeping parliament and the executive within its limits, as set by the legal framework.

While in law there is a distinction between 'courts' and 'tribunals', ${ }^{49}$ even persons (whether legally qualified or otherwise) presiding over tribunals are expected to perform judicial functions, for they too draw legitimacy from the state's monopoly over the judicial power. ${ }^{50}$ Both courts and tribunals are required to act judicially and apply the law without fear or favour. ${ }^{51}$ In the Indian context, the common law understanding of the rule of law, including its independence and adherence to a fair and identified procedure, applies to both courts and tribunals. International obligations, to the extent not inconsistent with domestic law, are also applicable. Increasingly, Indian domestic law is being tested on the anvil of the concept of rule of law, which includes fair trial guarantees whose content is supplemented by international human rights law. ${ }^{52}$ The rule of law also inheres in the application of the law to protect human rights and distinguishes the rule of law from rule by law. In other words, the march is towards 'Rechstaat' ${ }^{53}$

Against this broad overview of the concept of the rule of law, this article now turns to identify the specific factors relevant to an assessment of the FTs. It is contended that for a tribunal to be valid under Indian law, it is fundamental that it passes the following test.

First, the establishment of a tribunal must be by a validly enacted law, consistent with the requirements of the rule of law and the constitution. This is the law governing the creation, establishment and powers of the tribunal. ${ }^{54}$ The purpose of this approach is to ensure that tribunals are independent and capable and remain so. This precept is on the basis that in a democracy, elected representatives of the people can debate, deliberate and refine the law that are to apply to them, and any changes to the law would also need to undergo the same process that ensures no despotic bureaucrat can change the structure of the laws overnight. Such a restriction in the Constitution, in addition to the precepts of the rule of law, also flows from art 323-B of the Constitution, which requires creation of tribunals by laws made by legislature.

Second, the tribunal must be capable, competent, independent, fair and protected from external influence and must be able to act judicially.

48 See Lord Bingham, 'The Rule of Law' (2007) 66(1) Cambridge Law Journal 67.

49 See Bellur Narayanaswamy Srikrishna, 'The Indian Legal System' (2009) 36(2) International Journal of Legal Information 242.

50 One broad distinction that is necessary to make at this juncture - by and large, the tribunals in India do not have the power to order detention or to regulate custody of any person. This power has been vested with magistrate's courts alone.

51 See Arun K Thiruvengadam, 'Tribunals' in Sujit Choudhry, Madhav Khosla and Pratap Bhanu Mehta (eds), The Oxford Handbook of the Indian Constitution (Oxford University Press 2015) 412.

52 Naorem Sanajaoba, 'International Dimensions of Human Rights and International Obligations of India' (1998) 40(1/4) Journal of the Indian Law Institute 87.

53 See N W Barber, 'The Rechtsstaat and the Rule of Law' (2003) 53(4) The University of Toronto Law Journal 443; Loammi C Blaau 'The Rechtsstaat Idea Compared with the Rule of Law as a Paradigm for Protecting Rights' (1990) 107 South African Law Journal 76.

54 The Illegal Migrants (Determination by Tribunal) Act, 1983 (n 28) provided for such safeguards. 
Third, there must be a publicly known and pre-determined procedure and the procedure that the tribunal is required to apply must be just, fair and clear.

Before turning to an assessment of the FTs against this criteria, the next section provides a brief explanation of the context in which the FTs function, followed by legal issues in the setting up, administration and functioning of the FTs.

\section{THE FT IN ASSAM}

\section{A Establishment of the FT}

As an incident of sovereignty, the state has the power to regulate the presence of persons on its soil. ${ }^{55}$ Such persons can either be its citizens or non-citizens; but such a process does need to adhere to the rule of law. In the Indian context, the Foreigners Act, 1946 empowers the Central Government to regulate the entry, presence and departure of foreigners in India. The Foreigners Act, 1946 defines its purposes as an $A c t$

to provide for the exercise by the Central Government of certain powers in respect of the entry of foreigners into India, their presence therein and their departure therefrom. ${ }^{56}$

The Foreigners Act, 1946 does not contain any provision that creates or regulates the FT. In other words, the legislative will to create a FT as a system of adjudication is absent.

The reason why the issue of the 'creation of the tribunal' is relevant from a constitutional and administrative law perspective is that the manner and purpose of creation determine the delegation, regulation and (ab)use of its power. The purpose of the Foreigners Act, 1946 is neither to verify the citizenship status of a given population nor to adjudicate whether a person is an 'illegal immigrant'. The purpose of the Foreigners Act, 1946 is limited to the narrow determination of whether a person 'is not a foreigner' and it is legislation that was enacted in the backdrop of World War II. Those familiar with framing a charge in criminal cases or framing of issues in civil cases would appreciate that the issue of whether a person 'is not a foreigner' is distinct from whether a person 'is a citizen of India', and certainly distinct from the issue whether a person 'is a citizen of Bangladesh' as is often alleged for those accused of being a foreigner in the context of Assam. In fact, it is highly doubtful whether courts in India can adjudge a person to be a national of another country, say Bangladesh. ${ }^{57}$ Thus, a legally untenable process

55 See Virginie Guiraudon and Gallya Lahav, 'A Reappraisal of the State Sovereignty Debate: The Case of Migration Control' (2000) 33(2) Comparative Political Studies 163.

56 Foreigners Act, 1946 (n 10) preamble.

57 In Cruz City 1 Mauritius Holdings v Unitech Limited [2017] 239 DLT 649 (Delhi High Court) [23], the Delhi High Court (in the context of arbitration) has held: 
is being applied to determine whether some of the Indian residents are Indian citizens. In international law, there is a clear distinction between 'statelessness determination', 'citizenship determination' and 'citizenship re-verification'. ${ }^{58}$ In its simplest formulation, in order to satisfy the test of proportionality, it must be established that there is a rational nexus between the means to achieve a legitimate end, and that there is no other less intrusive or harmful alternative. ${ }^{59}$ Given this analysis, it is doubtful whether the Foreigners Act, 1946 providing for 'determination of foreigner status' is a proportionate tool for citizenship 'verification' - because in the garb of determination of citizenship, a state cannot arbitrarily strip their citizens of nationality.

In the Indian context, laws enacted by parliament are presumed to be valid unless held otherwise. However recently, the Supreme Court of India in Navtej Singh Johar $v$ Union of India has held that

Where, however, a pre-constitution law is made by either a foreign legislature or body, none of these parameters obtain. It is therefore clear that no such presumption attaches to a pre-constitutional statute like the Penal Code. ${ }^{60}$

The houses of parliament that, after the adoption of the Constitution, consider themselves constrained by the fundamental rights enshrined in Part III of the Constitution had no opportunity to deliberate on the law before passing the Foreigners Act, 1946.61 Therefore, in the event of a legal challenge to the Foreigners Act, 1946, the burden of proving that the law is not opposed to the Constitution would be upon the government. This is particularly important because this burden to prove that legislation is valid is a procedural limitation on the sovereign powers of the state. In the international context, this makes India an example of the fact that, in addition to government being constricted by international law, ${ }^{62}$ they could find their sovereign power to determine citizenship controlled or limited by their domestic law.

In fact, in Hans Muller of Nurenburg $v$ Superintendent, Presidency Jail, 63 the then-Attorney General for India had admitted to the fact that the then s 4 of the

Any decision with regard to enforcement of the award by this Court may not have any
bearing on the validity of the award or its enforceability in other jurisdictions.
However, the question whether the award will be recognised and enforced in India,
cannot be adjudicated by the arbitral tribunal, the Courts in United Kingdom or for that
matter any other country; only the courts in this country are competent to consider
whether the award is to be recognised and enforced in this country. The principle of
res judicata is applicable only where the issue/controversy is finally decided by a
court/forum of compete jurisdiction and - although prior decision on the issue by a
court in another country may be persuasive - neither the decision of the Arbitral
Tribunal nor of the High Court of Justice regarding enforceability of the award, is
binding on this court. Since, the determination of nationality is an incident of sovereignty. Therefore, only the courts of the concerned country can decide whether a person is a national of that country or not.

58 See generally Benjamin N Lawrance and Jacqueline Stevens (eds), Citizenship in Question: Evidentiary Birthright and Statelessness (Duke University Press 2017).

59 Aharon Barak, 'Proportional Effect: The Israeli Experience' (2007) 57(2) The University of Toronto Law Journal 369, 374.

60 [2018] 10 SCC 1 (Supreme Court of India) [344].

61 India gained independence on 15 August 1947 and the Constitution (n 43) was adopted on 26 November 1949.

62 Peter J Spiro, 'A New International Law of Citizenship' (2011) 105(4) American Journal of International Law 694.

63 [1955] 1 SCR 1284 (Supreme Court of India) [17]. 
Foreigners Act, 1946 was invalid after the adoption of the Constitution, in view of a specific non-derogable guarantee of protection from arbitrary and whimsical treatment provided in art 14 of the Constitution. ${ }^{64}$ This protection has been interpreted by the Supreme Court of India to extend even to foreigners. ${ }^{65}$ It is also significant that the FT is not mentioned in Article 323-B of the Constitution, which means that the setting up of a tribunal for the determination of 'foreigner' status is not expressly contemplated in the Constitution. Arguably, it may still fall within the residual legislative power of the Union Government and as an incident of the inherent right of a sovereign nation. ${ }^{66}$

In exercise of its powers under s 3 of the Foreigners Act, 1946, the Central Government issued an executive order called the Foreigners (Tribunals) Order, 1964 ('FTO'). ${ }^{67}$ Paragraph [2](2) of the FTO empowers the Central Government to appoint FTs consisting of such number of persons having judicial experience as it may think fit to appoint. Paragraph [2](1) of the FTO empowers the Central Government to

refer the question as to whether a person is not a foreigner within the meaning of the Foreigners Act, $1946 \ldots$ to a Tribunal to be constituted for the purpose, for its opinion.

The FTO was amended in May 2019 to empower the FT to also entertain 'appeals' against exclusions preferred by those excluded from the final list of the NRC in Assam. ${ }^{68}$ It is relevant that the FT is required to answer the reference sent to it, and to render an 'opinion' (as distinct from a judgment, decree or order). In practice, this allows an officer (a litigant) on whose reference the opinion is rendered to adversely comment upon the same and recommend that the opinion be challenged before the High Court.

Thus, it is apparent that FTs have not been created by 'law enacted by parliament'. This is crucial because recently in Roger Mathew $v$ South Indian Bank ('Roger Mathew'), the Supreme Court of India has re-confirmed that as long as broad legislative guidance or policy is provided for in the legislation creating a tribunal, it is constitutional that the workings of a tribunal are left to be provided by resorting to the rule-making power. ${ }^{69}$ In the case of FTs in Assam, as they have not been created by a law passed by parliament, this legislative guidance is absent. The Foreigners Act, 1946, a pre-constitutional statute, is completely silent even on setting up of FTs, let alone providing any guidance. Thus, whether one looks at FTs from the yardstick given by Gogoi CJ (majority) or that given by Deepak Gupta J (dissenting) in Roger Mathew, FTs are not lawful.

It is also significant that orders issued by the Central Government under [3] (such as the FTO) are not required to be tabled before parliament, whereas those

64 Constitution (n 43) art 14: 'The State shall not deny to any person equality before the law or the equal protection of the laws within the territory of India'.

65 Railway Board v Chandrima Das [2000] 2 SCC 465 (Supreme Court of India). The Supreme Court of India held that a Bangladeshi national who was sexually assaulted in India could approach the Indian constitutional courts for enforcement of fundamental rights of equality and of due process.

66 See Union of India v Delhi High Court Bar Association [2002] 4 SCC 275 (Supreme Court of India) 285 [12].

67 Foreigners (Tribunals) Order, 1964 (India) GSR 1401 of 1964.

68 See Foreigners Tribunals (Press Release, Press Information Bureau 11 June 2019) $<$ https://pib.gov.in/PressReleseDetailm.aspx?PRID=1573947>; Foreigners (Tribunal) Amendment Order, 2019 (n 40).

69 Civil Appeal No 8588 of 2019 (Supreme Court of India). 
orders issued under s 3A of the Foreigners Act, 1946 concerning exemptions from the application of foreigners orders are required to be tabled before parliament. This shows a complete lack of parliamentary control over delegated legislation with respect to a legislation dealing with arrest, detention and internment.

\section{B Selecting Members for the FT}

While scholars have disagreed on the precise content of the rule of law, ${ }^{70}$ there is no denying that the existence of an independent and a capable court or tribunal to protect a person from arbitrary laws or the arbitrary application of laws is central to the rule of law. The degree of independence of the court or tribunal is to be determined with reference to the domestic law, the constitution and any applicable principle of law that governs the field. Capability again is subjective, but experience shows that across statutes under the Indian legal system, offences involving minor punishments are adjudicated upon by a magistrate who, whilst having prescribed legal qualifications, has lesser judicial experience and training than those adjudicating offences involving major punishments, who are not only senior in age but also in judicial experience and judicial training.

The necessity of having competent and qualified judges flows from the principle of the rule of law that requires adjudication to be made by capable judges who have the requisite skills and who have undergone training to reduce any chances of error. The absence of any of these would affect the legitimacy and moral authority of the judicial power of the state.

The capability of a judge in a given context is framed with reference to merit, legal training, judicial training and experience as a judge. In India, this is captured in differing qualifications for appointments as a magistrate, sessions judge, judge of the High Court and judge of the Supreme Court. Similarly, a specified qualification has been prescribed for appointment of members to various tribunals that requires them to hold specified judicial experience. Thus, for instance, those chosen to preside in tax tribunals must have training and experience in the administration of tax system and adjudication of the tax regime. The Constitution has permitted 'tribunalisation' on the premise that an 'expert', to determine technical issues, would provide speed and accuracy to the adjudication process. ${ }^{71}$ It is for this reason that areas of law such as the recovery of money, possessions, marriage and divorce are still reserved for ordinary courts and areas such as tax, anti-trust, employment matters, etc have been transferred to specialised tribunals.

70 See Svend-Erik Skaaning, 'Measuring the Rule of Law' (2009) 63(2) Political Research Quarterly 449; Mila Versteeg and Tom Ginsburg, 'Measuring the Rule of Law: A Comparison of Indicators' (2017) 42(1) Law \& Social Inquiry 100. UDHR (n 46) art 8 provides: 'Everyone has the right to an effective remedy by the competent national tribunals for acts violating the fundamental rights granted him by the constitution or by law'.

71 L Chandra Kumar v Union of India [1997] 3 SCC 261 (Supreme Court of India) [88] (emphasis added):

A Tribunal which substitutes the High Court as an alternative institutional mechanism for judicial review must be no less efficacious than the High Court. Such a tribunal must inspire confidence and public esteem that it is a highly competent and expert mechanism with judicial approach and objectivity. What is needed in a tribunal, which is intended to supplant the High Court, is legal training and experience, and judicial acumen, equipment and approach.

See also T C A Anant and Jaivir Singh, 'Structuring Regulation: Constitutional and Legal Frame in India' 41(2) Economic and Political Weekly 121. 
In $R$ K Jain v Union of India, the Supreme Court of India has held that a person appointed to 'Tribunals' must have legal expertise, judicial experience and a modicum of legal training as on many an occasion different and complex questions of law would arise for discussion and decision. ${ }^{72}$ In Pareena Swarup $v$ Union of India, the Supreme Court of India has held that as judicial powers were to be exercised by the Appellate Tribunals under the Prevention of Money-Laundering Act, 2002, the constitutional courts were obliged to protect the constitutional guarantee of independence of judiciary. ${ }^{73}$ Thus for instance if the law allows the executive to appoint a natural person sympathetic to its cause or a person who is not trained to resist influence, such a law would be unconstitutional. The freedom from control and potential domination of the executive are necessary preconditions for judicial independence, and one of the ways in which control over a judge could be exercised is by modifying the selection criteria and regulating the terms of appointment. Thus, the qualification of judges affecting his or her independence and capability is regarded as an essential component of the rule of law. ${ }^{74}$ Under the Indian law the constitution, qualification and service conditions of the judges or members of a tribunal are required to be regulated by law. However, it is not the case when it comes to FTs. In the next section, this article will look at how FTs are established and controlled by the executive rather than the legislature.

In so far as the appointment of judges/member to the FTs is concerned, [2](2) of the FTO (and not the Foreigners Act, 1946) provides that ' $[\mathrm{t}]$ he tribunal shall consist of such number of persons having judicial experience as the Central Government may think fit to appoint'. Recall that the Foreigners Act, 1946 is completely silent on the specific qualification and expertise of members or judges who are to preside such tribunals, leaving it in the hands of the executive to pick and choose the judges who are required to preside over the tribunal without any control of the legislature. The only limitation on the power of the Central Government arises from the use of the phrase of 'judicial experience' in [2](2) of the FTO, whereas this should have been prescribed by legislature in the Act instead. Thus, the FTO is itself outside the constitutional limits.

It is relevant that, for example, monetary or civil issues dealing with appointment, termination, retrenchment etc of a workman are legislatively required to be adjudicated by the Industrial Disputes Act, $1947 .{ }^{75}$ Section 3 of the Industrial Disputes Act, 1947 provides that a person shall not be qualified for appointment as the presiding officer of a labour court unless he has held judicial office for a specified length of time. ${ }^{76}$

72 [1993] 4 SCC 119 (Supreme Court of India) [67].

73 (2008) 14 SCC 107 (Supreme Court of India) [9], citing Prevention of Money-Laundering Act, 2002 (India) Act No 15 of 2003.

74 Union of India v Namit Sharma [2013] 10 SCC 359 (Supreme Court of India); Union of India v Madras Bar Association [2010] 11 SCC 1 (Supreme Court of India).

75 Industrial Disputes Act, 1947 (India) Act No 14 of 1947.

76 ibid s 7(3):

A person shall not be qualified for appointment as the presiding officer of a Labour Court, unless-

(a) he is, or has been, a Judge of a High Court; or

(b) he has, for a period of not less than three years, been a District Judge or an Additional District Judge; or 
However, as previously discussed, there is no specific provision under the Foreigners Act, 1946 enabling the creation of a tribunal much less providing for any criteria for appointment, and the FTO is issued with reference to omnibus power of the Central Government to issue orders. Under the FTO, the requirement is only that of holding 'judicial experience', which has the power to decide on citizenship status resulting also in statelessness or even perpetual detention. ${ }^{77}$ This may be contrasted with eligibility conditions that have been provided for some other tax tribunals as well where minimum judicial experience are also spelt out. ${ }^{78}$

Interestingly, for the establishment of an Advisory Board for Preventive Detention, the Constitution art 22(4) requires that an advisory board must consist of persons who are, or have been, or are qualified to be appointed as, 'Judges of a High Court'. In other statutes where tribunals are contemplated, collegiate decision making is expected and a distinction is made between a judicial member and a technical member, where judicial members must have judicial experience and must bring reasonableness, fairness and impartiality to the table.

Thus, it seems ex facie incongruous that tribunals dealing with issues of status determination - where the question is whether a person is a foreigner and is permitted to regulate custody and detain or intern a person - does not even have a statutorily fixed eligibility condition. The power to appoint members of the FT, or even their conditions of service, is not statutorily regulated. Having regard to the provision of art 22(4) of the Constitution, ${ }^{79}$ it also appears that in so far as qualifications of the presiding judge are concerned, a foreigner who is 'preventively' detained is on a better footing than 'Indians', or even 'foreigners', who are detained indefinitely under the Foreigners Act, 1946 because they have not been able to disprove the allegation that they are foreigners.

\section{Applying the Criteria of 'Judicial Experience' to the Selection Process}

The sole restriction on the power to appoint members of FT arises from the use of the phrase 'judicial experience', which is extremely vague. The reason it is 'vague' is because, in practice, it appears that the Central Government, as well as the Gauhati High Court, have made (an untenable) distinction between 'judicial

(d) he has held any judicial office in India for not less than seven years; or

(e) he has been the presiding officer of a Labour Court constituted under any Provincial Act or State Act for not less than five years.

(f) he is or has been a Deputy Chief Labour Commissioner (Central) or Joint Commissioner of the State Labour Department, having a degree in law and at least seven years' experience in the labour department including three years of experience as Conciliation Officer...

77 Foreigners (Tribunals) Order, 1964 (n 67) [2](2).

78 Regarding the Customs Excise and Service Tax Appellate Tribunal, see Customs Act, 1962 (India) Act No 52 of 1962, s 129(2): 'A judicial member shall be a person who has for at least ten years held a judicial office'. Regarding the Income Tax Appellate Tribunal, see Income Tax Act, 1961 (India) Act No 43 of 1961, s 252(2): 'A judicial member shall be a person who has for at least ten years held a judicial office'.

79 Constitution (n 43) art 22(4) provides that:

No law providing for preventive detention shall authorise the detention of a person for a longer period than three months unless-

(a) an Advisory Board consisting of persons who are, or have been, or are qualified to be appointed as, Judges of a High Court has reported before the expiration of the said period of three months that there is in its opinion sufficient cause for such detention... 
experience' and 'having held judicial office'. Consequently, bureaucrats with some judicial experience, lawyers with enrolment experience and retired judicial officers have all been found eligible to be appointed as members of the FTs within the meaning of the phrase 'judicial experience' under [2](2) of the FTO.

By its judgment in Assam Sanmilita Mahasangha, the Supreme Court had directed the Guahati High Court to 'finalise the process of selection of the Chairperson and Members of the FT, if required in phases, depending on the availability of officers opting to serve in the Tribunals'. ${ }^{80}$ By using the phrase 'officers opting to serve', even the Supreme Court seems to be of the view that 'judicial experience' means 'holding judicial office' or in the least, 'having held a judicial office'. However, in 2019 an advertisement issued by the Gauhati High Court situated at Guwahati, the state capital of Assam, called for applications for appointment as Members of the FT of Assam by prescribing the following eligibility condition:

1. Qualification of the candidate:

(i) Should be citizen of India.

(ii) Retired Judicial Officers of Assam Judicial Service, or,

(iii) Retired Civil Servants (not below the rank of Secretary and Addl. Secretary) having Judicial experience, or,

(iv) Advocates not below the age of 35 years with at least 7 years of practice.

(v) The candidates will have to have fair knowledge of official language of Assam and its (Assam) historical background giving rise to foreigner's issues. ${ }^{81}$

The eligibility seems to provide for a 'free for all', in that it allows almost anyone 'connected' to the judicial system to be eligible for appointment as a member of the FT in Assam. The entry of civil servants and advocates as members of FTs is particularly problematic because their experience with the law and judicial system cannot exactly be termed as 'judicial experience'. In Badridass Kanhaiyalal $v$ Appellate Tribunal of State Transport Authority Rajasthan, ${ }^{82}$ the Rajasthan High Court held that

when the legislature lays down the qualification of the Chairman of the State Transport Authority with reference to judicial experience it should be assumed that the intention of the legislature is that a person must possess judicial experience in a substantial measure. Nominal judicial experience for a short period would not qualify a person to be appointed as Chairman of the State Transport Authority. ${ }^{83}$

This test applies squarely to bureaucrats who may have minimal experience of presiding over a quasi-judicial forum. The Rajasthan High Court had further held that "judicial experience" would mean the knowledge or skill gained by a person by actually working as a judge in a court of law' and a lawyer cannot be said to have judicial experience. ${ }^{84}$

In order to recruit more lawyers to preside over as members of the FT, compared to previous recruitments, the advertisement issued by the Gauhati High

80 Assam Sanmilita Mahasangha (n 37) [46](2).

81 'Advertisement' (Official Advertisement No HC XXXVII-22/2019/442/R.Cell, 10 June 2019) 1 [1] <http://ghconline.gov.in/Recruitment/Notification-10-06-2019.pdf> ('Judicial Advertisement') .

82 [1959] AIR 1960 Raj 105 (Rajasthan High Court).

83 ibid [58].

84 ibid [62]. 
Court in 2019 reduced the age limit from 45 years to 35 years, and diluted the requirement of experience from 10 years to 7 years. ${ }^{85}$ This goes to establish the necessity to entrench the bare minimum eligibility conditions in the statute creating the tribunal, and not in delegated legislation that can be either changed overnight or interpreted capriciously by the appointing authority. Given the Supreme Court's orders on the NRC, ${ }^{86}$ Justice Gogoi's personal supervision ${ }^{87}$ of the case and a permissive direction to Gauhati High Court to monitor the creation and functioning of the Tribunal, the Gauhati High Court diluted the eligibility condition of appointing members to FTs and appointed over 200 members. It is also relevant that the power to create FTs and to appoint members under the FTO is with the Central Government. This power has been delegated to state governments.

In the advertisement referred to above, the first requirement is a person must be 'a citizen of India' and must have 'fair knowledge of official language of Assam and its (Assam) historical background giving rise to foreigner's issues'. ${ }^{88}$ This itself is likely to result in exclusion. Given that NRC required each and every person resident in Assam to apply for inclusion in the NRC list - who is 'citizen of India' is a contentious issue. In fact, is not that the very question that the FT must decide? This necessarily means that the eligibility criteria is itself a recipe to exclude 'suspect citizens' from even participating in the selection process to be appointed as members of FTs, and in the absence of any written examination or transparent selection process, the grounds for exclusion are never spelt out. This may be viewed in the backdrop of reports of serious bias in the administrative quarters against Bengali speaking Muslims in Assam. ${ }^{89}$

\section{Lack of Transparent Selection Process and Lack of Judicial Training}

It needs little elucidation that ordinarily any process for selection to a public post in India must provide for (a) fair and transparent public recruitment system; (b) adequate training; and (c) must adhere to rules of the reservation to enhance diversity. However, for Assam all legal rules are being ignored. The advertisement for the selection of members of FTs does not reflect that the principles of reservation for ensuring equal access to opportunity (the Indian version of

85 Sagar, 'Case Closed: How Assam's Foreigners Tribunals, Aided by the High Court, Function Like Kangaroo Courts and Persecute Its Minorities', Caravan (online, 6 November 2019) $<$ https://caravanmagazine.in/law/assam-foreigners-tribunals-function-like-kangaroo-courtspersecute-minorities $>$.

86 Assam Sanmilita Mahasangha (n 37).

87 See Mandhani (n 38).

88 Judicial Advertisement (n 81) 1 [1].

89 Arshia Dhar, 'Journalist Rohini Mohan on Her Assam NRC Reportage, "Breakdown of Fragile, Important Coexistence" in India', Firstpost (online, 23 December 2019) $<$ https://www.firstpost.com/india/known-for-extensive-assam-nrc-reportage-rohini-mohansays-india-is-seeing-breakdown-of-a-fragile-coexistence-7790921.html>.

There are groups, who, from the beginning of this process, said that it is completely biased against Muslims. But it took months of reporting to show that the NRC is also biased against the poor. So we need to keep an open mind. While it is targeted against the Muslims, it was also affecting more people, and that is why so many care about the CAA and NRC now. You may not care at all about the Muslims, but you do care about yourself and the poor.

See also 'India Strips Millions of Bengali Speaking Muslims of Citizenship in Assam', Daily Sabah (online, 30 July 2018) <https://www.dailysabah.com/asia/2018/07/30/india-stripsmillions-of-bengali-speaking-muslims-of-citizenship-in-assam $>$. 
affirmative action) has been adhered to. For example, s 10 of the Consumer Protection Act, 1986 provides that that every District Consumer Forum shall have a woman member. 90

Matters are only worsened by the fact that such members (mostly lawyers) who are recruited are not provided with any substantial training in being judges and only attended a four-day training seminar. ${ }^{91}$ It is also not clear what they are 'taught' in those four days. This may be contrasted with the United Kingdom, where the Judicial College (earlier Judicial Studies Board) provides training to members of tribunals functioning there on aspects such as appreciation of evidence, dealing with conflicting evidence, admissibility of evidence and other practical guidance. ${ }^{92}$

Given that the 'problem' of 'outsider' has persisted in Assam for a long time, and now 1.9 million cases of those excluded from the NRC are to be decided by FTs, it is only proper that the government should create a sub-stream of qualified and independent judicial officers to decide these cases in the decades to come.

\section{E Members of FTs Lack Decisional Autonomy}

The independence of an adjudicating authority is central to the rule of law. The independence of an adjudicating authority means freedom from prejudices as well as the ability to decide a case only on its merit. In this context, one of the biggest challenges faced by FTs is the determination of the identity of an individual. As a general rule, the identity of the person being proceeded against or tried is irrelevant - but in FTs it is the identity that is to be established. Therefore, there is a compelling case to ensure that the adjudicating authority does not get prejudiced by any dominant socio-political discourse on who is a foreigner and who is a citizen, and retains the ability to appreciate and apply a pre-determined set of rules independently.

The FTs in Assam have adjudicated 129,009 cases, ${ }^{93}$ of which more than $60 \%$ are orders passed without the presence of the person concerned. ${ }^{94}$ They are

90 Consumer Protection Act, 1986 (India) Act No 68 of 1986, s 10.

91 See Designed to Exclude (Report, Amnesty International 2019) $5<\mathrm{https}$ ://amnesty.org.in/wpcontent/uploads/2019/11/Assam-Foreigners-Tribunals-Report-1.pdf> ('Designed to Exclude').

92 The website of United Kingdom Judiciary described judicial college's Tribunal Committee in the following words:

As part of the Judicial College each tribunal delivers a training programme for judges and members who sit in that jurisdiction. The Tribunals Committee has overall responsibility for tribunals judicial training with jurisdiction in England and for reserved tribunals in Scotland, Northern Ireland and Wales. The committee carries out general high level oversight of judicial training across tribunals and will, when appropriate, take account of the interests of devolved tribunals and those tribunals which subsequently transfer into HMCTS.

See 'Tribunals' Courts and Tribunals Judiciary (Web Page) $<$ https://www.judiciary.uk/about-the-judiciary/training-support/judicial-college/tribunals/>.

93 Unstarred Question No 3558 Answered on 10 Dec 2019 (Letter, Parliament of India, 2019) $<\mathrm{http}: / / 164.100 .47 .194 /$ Loksabha/Questions/QResult15.aspx?qref=10079\&1sno=17>.

94 Unstarred Question No 1724 Answered on 2 July 2020 (Letter, Parliament of India, 2020). $<$ http://loksabhaph.nic.in/Questions/QResult15.aspx?qref=1909\&1sno=17> （'Unstarred Question No 1724').

63959 (sixty three thousand nine hundred fifty nine) persons have been declared foreigners through ex-parte proceedings by Foreigners' Tribunals in Assam from 1985 to 28th February, 2019. 
destined to adjudicate at least another 1.9 million cases. Thus, it is apparent that FT are here to stay. However, the appointment of members of the FT, even under the most recent advertisement, is initially for a period of one year, which may be extended from time to time, and their retirement age is fixed at 67 years. The Supreme Court in Supreme Court Advocates-on-Record Association v Union of India, has noted that the independence of the judiciary comprises of two broad concepts. ${ }^{95}$ Firstly, the independence of an individual judge, that is, decisional independence. Secondly, the independence of the judiciary as an institution or an organ of the state, that is, functional independence.

Appointments procedure for various other tribunals in India establish that members of other tribunals enjoy protection from the arbitrary termination of their services. In the case of FTs, reports have revealed that whether a contract of a member would be renewed depends on the nature of the orders that he has passed. ${ }^{96}$ The more the number of persons adjudicated as foreigners, the higher the chances of renewal of contract or extension of the term as members of the FT. Therefore, it is hard to conclude that members of the FTs, even when capable and qualified, enjoy decisional independence. ${ }^{97}$

As far as functional independence is concerned, in Assam Sanmilita Mahasangha, the Supreme Court directed the Gauhati High Court to 'supervise' the functioning of the FTs every month. ${ }^{98}$ This opportunity, more than the power under art 227 of the Constitution, was seized by the Gauhati High Court to 'audit' the orders passed by the tribunals, adversely affecting the decisional as well as functional independence of the tribunals. In fact, the committee established by the Gauhati High Court permitted the Border Police referring cases to FT to comment on the 'opinion' of the tribunal and advise the state government on whether the opinion is to be challenged. ${ }^{99}$ Since the authority making a reference is required to 'investigate', such an approach adopted by the High Court actually merges the role of 'investigator' and a 'prosecutor' in the context of reverse burden of proof. It is thus hard to conclude that the FT enjoy the functional independence that they ought to.

\section{Procedure Followed By FTs}

Before we discuss the procedure, it must be kept in mind that the purpose of the Foreigners Act, 1946, set up in the post-World War II context and replacing the previous Foreigners Act, 1940 and Foreigners Act, 1864, was to summarily remove the foreigners in India. Neither the Foreigners Act, 1946 nor the FTO are designed to re-verify the citizenship status of Indian nationals. Subsequent to the judgment in Sonowal I, 100 the government had introduced Foreigners (Tribunals for Assam) Order, 2006, ${ }^{101}$ which sought to provide certain checks which were absent in the FTO. However, the Supreme Court of India struck it down in

95 [2016] 5 SCC 1 (Supreme Court of India) 594.

96 Sagar (n 85).

97 See also The Bangalore Principles of Judicial Conduct (Principles, Judicial Group of Strengthening Judicial Integrity 26 November 2002).

98 Assam Sanmilita Mahasangha (n 37).

99 It is highly doubtful that the power conferred on the High Court could be delegated to a committee.

100 Sonowal I (n 31).

101 See Foreigners (Tribunals for Assam) Order, 2006 (India) GSR 58(E). 
Sarbananda Sonowal v Union of India ('Sonowal II'), 102 on the grounds that it dilutes the judgment rendered by it in the earlier round of litigation. ${ }^{103}$ Thus, the effect of both the Sonowal judgments is that it is permissible to have a separate citizenship regime for a resident of Assam, but it is impermissible to have a separate procedural regime for 'verification' of citizenship in Assam.

\section{A Due Process Guarantees Are Not Available in FTs}

The limited procedure that is to be followed by FT is set out in [3] of the FTO. Under the marginal heading of 'Procedure for Disposal of Questions', [3] enables a person to be given a

reasonable opportunity of making a representation and producing evidence in support of his case and after considering such evidence as may be produced and after hearing such persons as may desire to be heard.

Such a succinct procedural rule must be considered in the backdrop of the reverse burden of proof specifically mandated by s 9 of the Foreigners Act, 1946.

Thus, where a reference is made against a person by the Assam Border Police or by the Election Commission or by the State Government, a person is presumed to be a foreigner and the burden is upon him or her to establish that the person is not a foreigner. It was not clear until recently whether the reverse burden of proof was to be discharged 'beyond reasonable doubt' or 'on a preponderance of probabilities'. ${ }^{104}$ However, given that the tribunals reject the evidence and declare persons as foreigners for minor technicalities or flaws - including the English spelling of the name of persons's ancestors 105 — it could be argued that the yardstick that is being applied is 'beyond reasonable doubt'. It is only recently that the Gauhati High Court has clarified that the strict rules of evidence are not applicable to FTs and nothing is required to be proven beyond reasonable doubt. ${ }^{106}$ In this case before the High Court, the FT had declared a person to be a 'foreigner' as his name was not included in the voters' list of 1975, even though he had attained voting age by then. The Tribunal had also ignored the facts his father's name was included in the voters' list of 1965 and his name was included in the voters' list of 1985 and 1989. ${ }^{107}$ The High Court held that the Tribunals were not to expect the person to prove his citizenship beyond reasonable doubt.

It is interesting that while insisting upon and justifying the application of 'reverse burden of proof' in citizenship regime in Sonowal I, the Supreme Court of India relied upon, inter alia, s 188 of the Australian Migration Act, 1958 and certain others. ${ }^{108}$ It is arguable that even under Indian law, prior to making a

102 [2007] 1 SCC 174 (Supreme Court of India) ('Sonowal II').

103 Sonowal I (n 31).

104 Idrish Ali v Union of India [2020] Case No WP(C) 4116/2019 (Guahati High Court) ('Idrish Ali').

105 Report of Public Hearing On Statelessness and Marginalisation in Assam in February (Report, Human Rights Law Network 2019) $21<\mathrm{https} / / \mathrm{hrln}$.org/wpcontent/uploads/2019/06/Report-of-Public-Hearing-on-NRC-and-CAB.pdf $>$.

106 Idrish Ali (n 104) 4.

107 ibid 3-4.

108 Sonowal I (n 31). Migration Act 1958 (Cth) (Australia) s 188 triggers reverse burden only when '[a]n officer may require a person whom the officer knows or reasonably suspects', and further allows the person (subject to regulations) to produce oral evidence as well. Therefore, it is hard to conclude that Australian law has full reverse burden of proof akin to what is presently being applied by Foreigners Tribunal in India. 
reference to the tribunal, the authority making a reference must satisfy itself of the existence of reasonable grounds whether or not a person should be subjected to the process of the status determination under the FTO. However, in practice, the references are mechanically made 109 — and there is no mechanism that is deployed to 'filter' out bad references by requiring to establish a prima facie case — as that is exactly what the Foreigners (Tribunals for Assam) Order, 2006 sought to do, which was invalidated by the Supreme Court in Sonowal II. ${ }^{110}$

The procedural rules further provide for the issuance of a show cause notice to the person concerned, indicating that the burden of proof is upon him and requiring him to reply within 10 days. The rules also provide for a mechanism for service of a 'show cause' notice upon the 'proceedee' (a term used for a person accused to be a foreigner). However, in practice, this is not observed and it is reported that out of approximately 129,009 determinations made by FTs, 63,959 are ex parte ${ }^{111}$ - passed without giving an opportunity of hearing to the person affected. ${ }^{112}$ The officers who are required to make the report of service of the show cause notice often do not even bother to check whether the person who is served is actually the person concerned or any other who shares the same name. Sometimes the migrant labourers who are accused of being foreigners are not found at the temporary address that they take, which is noted by the police at the time of inquiries. ${ }^{113} \mathrm{In}$ many cases, show cause notices are not actually served by the police. These aspects are also not adequately verified by FT. This could be because their 'disposal rates' as well as declaration as foreigner rates are being 'monitored' by the High Court and the Committees appointed by the High Court, and therefore there is an urgency to decide cases ${ }^{114}$ — even if that means not hearing the person accused of being a foreigner. This is more so when the renewal of contracts to continue as members of FTs, and to draw remuneration for the same, depends upon their 'performance' being 'monitored' by external agencies. ${ }^{115}$ It follows that that

109 See Manu Sabastian, 'Ex-Army Man, Who Was Detained after Being Declared a "Foreigner" by Assam Tribunal, Moves Guahati HC for Release', Live Law (online, 1 June 2019) $<$ https://www.livelaw.in/top-stories/ex-army-man-who-was-detained-after-being-declareda-foreigner-moves-guahati-hc-for-release-145395>. This article highlights that the reference concerning Mohammad Sanaullah, who served in the Indian army from 1987 to 2017, Assam Border Police in 2008 mentioned his profession as 'labour'. The article also mentions that after retirement from army, Sanaullah was working as sub-inspector in the Assam Border Police. Interestingly, the reference made by Assam Border Police relies on Sanaullah's confessional statement where he admits to being born in Dhaka, Bangladesh.

110 See Sonowal II (n 102).

111 Unstarred Question No 1724 (n 94).

112 ibid. The proceedings are ex parte on account of non-adherence to the rules that have detailed procedure about how service is to be effected.

113 Ipsita Chakravarty, 'Special Report: Ex Soldier Was among 100-Plus 'Foreigners' Held in Assam in Post-Poll Drive', Scroll.in (online, 3 June 2019) $<$ https://scroll.in/article/924958/post-lok-sabha-elections-assam-has-seen-a-spurt-indetentions-of-those-declared-foreigners $>$.

114 Due to external watch on performance, members of the FTs could be in a hurry to pass exclusion order, for their functioning is reviewed monthly and being seen as accommodating may result in non-renewal of contract. Failure to produce a document and the maker of that official document results in exclusion of that document from consideration due to reverse burden of proof.

115 Fatima Khan, 'Job in Assam Foreigners Tribunal Depends on Conviction Rate, Says Civil Rights Group Report', The Print (online, 19 September 2019) <https://theprint.in/india/jobin-assam-foreigners-tribunal-depends-on-conviction-rate-says-civil-rights-groupreport $/ 294030 />$. 
the FTs lack 'decisional autonomy' 116 and unlike other ordinary judges in other courts of India, they are not insulated from arbitrary changes in service conditions. This decisional autonomy is central to the existence of a fair adjudicatory mechanism.

Paragraph [3](9) of the FTO provides that the FT may refuse a prayer for examination of witnesses on commission for production of documents if, in the opinion of the FT, such a prayer is made to delay the proceedings. Given that the function and disposal rates of the FTs are being monitored by the High Court, which is also linked to extension of the contracts of the members of the FT, there is a premium in not investing further time by granting an opportunity to crossexamine and expeditiously close the proceedings, usually by declaring the person as a foreigner.

The procedural rules empower the FT to receive evidence from the Superintendent of Police and even third parties with no apparent restrictions on locus standi. Interestingly, where documents are produced by the proceedee to establish that he has been living in Assam prior to 1971, the proceedee is expected to secure the attendance of the person issuing the document to personally come and prove the due execution and genuineness of the content of the document. ${ }^{117}$ In a situation where the proceedees are generally powerless, there is no reason why a government officer issuing a 'duplicate' document for use in FT proceedings would, at his request (and expense), travel to a FT to depose.

In fact, the FT was empowered in 2013 by insertion of [4] into the FTO to exercise the powers of a civil court and that of the magistrate to summon any person and examine them on oath and to require the production of any document. However, such powers are not resorted to as the FTs feel obliged to decide the case expeditiously (within 60 days) using reverse burden as the reason to not exercise their powers to summon documents or officers at the expense of the state - but for the person accused of being a foreigner to bring such persons to the FT. The FT also has the power to order internment or detention or to grant bail to the person being accused of being a foreigner on the subjective basis of whether or not the procedure has been able to establish, prima facie, that they are not a foreigner. The amendments to FTO in 2013 also empowered the FT to set aside in absentia orders after the proceedee has shown sufficient cause. It also empowered the FT to review its judgment on the ground of any mistake apparent on the face of record. ${ }^{118}$

\section{B FTs' Power to Devise Their Own Procedure}

FTs are also empowered to regulate their procedure for disposal of cases expeditiously in a time bound manner. ${ }^{119}$ In the State of Assam, 100 tribunals have been functioning and 200 more tribunals were established in 2019. It is not hard to imagine that each of the 300 (or more) tribunals have the power to regulate their own procedure, and consequently, different rules and procedure are likely to be

116 See John Ferejohn, 'Independent Judges, Dependent Judiciary: Explaining Judicial Independence' (1998) 72(2-3) Southern California Law Review 353.

117 See for instance, the Gauhati High Court judgment in ManowaraBewa@ Manora Bewa v Union of India [2017] Case No WP(C) 2634 of 2016 (Gauhati High Court). This judgment, on another aspect, was reversed by the Supreme Court of India in Rupajan Begum v Union of India [2018] 1 SCC 579 (Supreme Court of India).

118 Foreigners (Tribunal) Amendment Order, 2013 (India) GSR 770(E), inserting Paragraph 3C.

119 ibid. 
devised and applied. It is peculiar that in India, for instance, National Company Law Tribunals, which are a few in number, have extensive rules to regulate their procedure. ${ }^{120}$ However, the government has left 300 FTs in Assam to come up with their own procedure, which is a recipe for unequal application of the law and discretion. The rule-making power is essentially legislative in nature, but parliament could lawfully delegate to the courts the power to vary minor regulations in the outlines marked out by parliament. However, in the present case, even the outlines of the procedural rules are not provided by parliament. While some guidance is provided under the $F T O$, the procedure is sufficiently vague and discretionary. For instance, FTs can refuse a prayer for cross-examination of witnesses if the FT is of the view that such a prayer is made to delay the proceedings. ${ }^{121}$ Having regard to the fact that a person in this case could be rendered stateless, the right to cross-examine or to adduce documents ought not to be in the realm of discretion but should be provided as of right by procedural rules.

As a consequence of this power to regulate their own procedure, the FTs have become opaque ${ }^{122}$ - anathema to the rule of law. Journalists have reported that FTs do not allow them access to sit through the proceedings; and, in many cases even relatives of the proceedees are not allowed to attend the proceedings. ${ }^{123}$ The Supreme Court has explained the necessity and merits of public access to courts and tribunals in Swapnil Tripathi v Supreme Court of India, ${ }^{124}$ and therefore it is against the rule of law to have 'justice' behind closed doors. Many of the persons accused of being a foreigner have alleged bias in the manner proceedings are conducted and therefore there is a compelling argument to allow journalists and members of the public to witness the proceedings of the FTs in Assam. ${ }^{125}$ Such a bias has also been reflected in recent developments, where a member of a tribunal made a donation to state government's 'Health Fund' but with a caveat that it should not be used for 'tablighi jamaat, jihadi and jahil' — insinuating Muslims. ${ }^{126}$

Interestingly, there is no provision in the FTO that obliges FTs to ensure legal assistance/legal aid to the proceedees. Arguably, the state is duty-bound to provide legal aid, ${ }^{127}$ but given the systemic issues with FTs, it would not be more than

120 See National Company Law Tribunal Rules, 2016 (India) GSR 716(E).

121 Foreigners (Tribunals) Order, 1964 (n 67) [3](9).

122 Teesta Stealvad, "Foreign Journalists Ask to "Leave" Assam, Post NRC: State Declared "Protected Area", CJP (online, 4 September 2019) <https://cjp.org.in/foreign-journalistsask-to-leave-assam-post-nrc/>. See also Lawfulness of Detention of Declared Foreigners in Assam under International Law (Report, South Asia Human Rights Documentation Centre 8 September 2019)

$<$ https://www.dtp.unsw.edu.au/sites/default/files/u4/Lawfulness\%20of\%20Detention\%20of $\% 20$ Declared $\% 20$ Foreigners\%20in\%20Assam-SAHRDC.pdf $>$.

123 Sagar (n 85).

124 [2018] 10 SCC 639 (Supreme Court of India).

125 'NRC: Fact-Finding Team Finds Anomalies, Bias in Functioning of Foreign Tribunals', National Herald $\quad$ (online, $20 \quad$ September 2019 ) $<$ https://www.nationalheraldindia.com/india/nrc-fact-finding-team-finds-anomalies-bias-infunctioning-of-foreign-tribunals $>$.

126 'Assam: Foreigners Tribunal Member Sends Donation to Govt for COVID-19, Urges Not to Aid Tablighi Jamaat Attendees', Inside NE (online, 11 April 2020) $<$ https://www.insidene.com/assam-foreigners-tribunal-member-sends-donation-to-govt-forcovid-19-urges-not-to-aid-tablighi-jamaat-attendees/ $>$. The said member later withdrew his letter and apologised for the same. The government subsequently issued him a show cause notice, and later his services were dispensed with.

127 Constitution (n 43) art 39A. 
mere lip service. Most of the persons alleged to be foreigners are impoverished and may not have the necessary documentation concerning ownership of properties, or documents to show that they were residents of Assam 50 years ago before the cut-off date of 24 March 1971. Thus, even if legal aid were to be provided, the reverse burden regime would operate oppressively.

In fact, a reading of some of the orders or 'opinions' of the FTs, and the orders passed by the High Court, establishes that many of the cases are lost by the persons accused of being foreigners because their lawyer either did not draft their response properly or relevant documents were not produced. Despite poor legal assistance, the Indian courts rarely apply the 'Strickland Test'. ${ }^{128}$ The same has not been applied so far in any of the FT cases. On the contrary, the High Courts have reasoned that parties have the autonomy to choose their lawyers, and if their lawyers fail to deliver, the consequences must be faced by the person who engaged such lawyers. ${ }^{129}$ For instance, the High Court held:

All that has been stated in the writ petition is that the petitioner is an illiterate and a poor person. This is no ground for remand. When the petitioner had engaged a lawyer to defend herself before the Tribunal, such averments on the face of it are untenable and cannot be accepted. ${ }^{130}$

However, the experience of lawyers shows that the High Court or the Supreme Court remands the matter for fresh adjudication by the FT when it is found that the FTs omitted considering a material aspect of the case - a natural consequence when people lacking 'judicial experience' preside over the FTs. ${ }^{131}$ For example, the High Court set aside an order passed by FT that had declared a serving officer in para-military force as a foreigner. ${ }^{132}$ This resulted in the person having to face the proceedings all over again.

There are various other gaps in the procedure. For example, there is no guiding principle available to doubt any person's citizenship and no prescribed standard

128 Strickland $v$ Washington [1984] 466 US 668 (United States Supreme Court). In this case, the United States Supreme Court held that where it could be shown that a person was given deficient legal assistance and such assistance resulted in prejudice to the person, the courts would regard that a person's Sixth Amendment right to effective legal assistance was violated. Roimon Nessa $v$ Union of India [2011] Case No WP(C) 1396 of 2011.

130 ibid [18].

131 Sabastian (n 109); 'Gauhati High Court Sets Aside 57 Orders of Foreigners Tribunal', The Sentinel (online, 25 September 2019) <https://www.sentinelassam.com/topheadlines/gauhati-high-court-sets-aside-57-orders-of-foreigners-tribunal/ $>$. This article notes that

A division bench of the Gauhati High Court comprising Justice Manojit Bhuyan and Justice Kalyan Rai Surana has set aside 57 cases ‘disposed off” by Foreigners Tribunal No. 4, Morigaon and ordered their fresh hearing.

The article notes that the High Court has also observed that

'before parting with the record, we express our disappointment over the way the Member conducted himself. This was not expected. In the ordinary course this would have called for some action, disciplinary or otherwise. We leave it at that'

The Gauhati High Court passed such an order in Xxxx v In Re - The State of Assam [2019] Case No WP(C)(Suo Moto) 11/2018.

132 Bikash Singh, 'Gauhati High Court Sets Aside Order of a Foreigners' Tribunal Which Declared Assistant Sub Inspector of BSF as Foreigner', The Economic Times (online, 7 September 2019) <https://economictimes.indiatimes.com/news/politics-and-nation/gauhatihigh-court-sets-aside-order-of-a-foreigners-tribunal-which-declared-assistant-sub-inspectorof-bsf-as-

foreigner/articleshow/71028181.cms\#: :text=GUWAHATI $\% 3 \mathrm{~A} \% 20 \mathrm{The} \% 20 \mathrm{Gauhati} \% 20 \mathrm{H}$ igh $\% 20$ court,matter\%20within\%20two\%20months'\%20time.>. 
or judicially applied requirement to be met before a show cause notice is to be issued. ${ }^{133}$ It is only now that the state government has promised to extend legal aid to those excluded from NRC. ${ }^{134}$ There is no appeal on facts against the order passed by the FTs. NGO from Assam have filed an application before the Supreme Court of India praying that procedure to be followed by the FT be prescribed by the Supreme Court itself. The procedure of 'appeal' in cases of exclusion from the NRC list that would govern the exclusion of 1.9 million persons is distinct and is not being discussed here.

The government has been assuring civil liberty groups that irregularities, if any, in the process of the determination of foreigners can be looked at by the High Court in the exercise of its writ jurisdiction, ${ }^{135}$ and then by the Supreme Court of India in an appeal to it. Therefore, one must not worry. The Supreme Court of India has also agreed with the same. ${ }^{136}$ However, the Supreme Court's trust upon the High Court's exercise of limited judicial review jurisdiction under art 226 of the Constitution is, to the say least, painting a rosy picture. Case after case the Gauhati High Court has consistently held that:

Such a finding being a finding of fact [arrived at by the FT], a writ Court exercising jurisdiction under Article 226 of the Constitution of India does not, ordinarily, interfere with such finding of fact unless there is perversity because the jurisdiction so exercised is supervisory and not appellate. ${ }^{137}$

At any rate, a limited judicial review under art 226 of the Constitution is not a substitute for a vested 'right of appeal' both on law and on facts. The appeals from High Court orders to the Supreme Court are rarely entertained, as the Supreme Court often refuses to decide the questions of fact in its discretionary appellate jurisdiction. ${ }^{138}$

\section{CONCLUSION: 'DESIGNED to EXCLUdE'}

The analysis in this article has identified many serious procedural concerns with the current process for identifying 'foreigners' in the Indian state of Assam. Assam's FTs are neither created nor regulated by statutory law, but by executive instructions and other delegated legislations. The FTs currently determining citizenship of local Indian residents in the Indian State of Assam involve a drastic system of adjudication and have limited procedural safeguards, which are discretionary and are not applied consistently. There is no effective 'appeal', but only a limited judicial review. While every step forward towards the functioning

133 In Sonowal II (n 102) [29]-[42]. The Supreme Court had expressed the faith that if the Central Government make an order making a reference to the FT, it must arrive at a subjective satisfaction that must be reflected in the order of reference. It further held that the same may be subject to the principles of the judicial review. However, such a power of the Central Government now stands delegated to various other state-level authorities. The Supreme Court's observation is sound in law but breached in practice.

134 'Assam Govt to Provide Legal Aid to "Needy People Excluded from Final NRC List", Says MHA; 200 New Foreigner Tribunals Set Up', Firstpost (online, 3 September 2019) $<$ https://www.firstpost.com/india/assam-govt-to-provide-legal-aid-to-needy-peopleexcluded-from-final-nrc-list-says-mha-200-new-foreigner-tribunals-set-up-7273821.html>.

135 Special jurisdiction of the High Courts in India to issue prerogative writs.

136 Abdul Kuddus v Union of India [2019] 6 SCC 604 (Supreme Court of India).

137 See, eg, Anowara Khatun v the Union of India [2019] Case No WP(C) 3038 of 2019 (Gauhati High Court).

138 Dhakeswari Cotton Mills Ltd v CIT [1955] 1 SCR 941 (Supreme Court of India) [7]. 
of the FT should ensure that due process is adhered to, the analysis in this article suggests that this is not the case. ${ }^{139}$ The framework of adjudication by FTs is not able to keep up with the promise of effective adjudication under the Constitution. In a damning report, Amnesty International has concluded that FTs in Assam are 'Designed to Exclude'. ${ }^{140}$ While such a conclusion implies an intention to exclude ('designed') - a contention that may be difficult to establish - the significant shortcomings outlined in this article go some way to establishing the legitimacy of this conclusion. What can be concluded with more certainty is that if, as widely expected, there is a nationwide roll-out of the NRC, such that similar FTs are replicated everywhere else in India, there is a genuine risk of very large numbers of persons being rendered stateless. There is clearly an urgent need for academic scrutiny of all aspects of the citizenship verification process in India. This article has provided the first comprehensive scrutiny of the procedural shortcomings. It is hoped that much more academic scrutiny will be applied to all aspects substantive and procedural - of this unfolding human rights crisis.

139 Constitution (n 43) art 21 provides: 'No person shall be deprived of his life or personal liberty except according to a procedure established by law'. See also Maneka Gandhi v Union of India [1978] 1 SCC 248 (Supreme Court of India) [7]:

The principle of reasonableness, which legally as well as philosophically, is an essential element of equality or non-arbitrariness pervades Article 14 like a brooding omnipresence and the procedure contemplated by Article 21 must answer the test of reasonableness in order to be in conformity with Article 14. It must be 'right and just and fair' and not arbitrary, fanciful or oppressive; otherwise, it would be no procedure at all and the requirement of Article 21 would not be satisfied. 